\title{
STRATEGI DP3AP2KB DALAM MEMBERIKAN PERLINDUNGAN DAN PENCEGAHAN KORBAN SODOMI SISWA SEKOLAH DASAR DI KOTA PADANG
}

\author{
Anggun \\ Jurusan Administrasi Publik, FIS Universitas Negeri Padang \\ E-mail: anggunkevin73@gmail.com \\ Aldri Frinaldi \\ Jurusan Administrasi Publik, FIS Universitas Negeri Padang \\ E-mail: aldri@fis.unp.ac.id
}

\begin{abstract}
As many as $56.46 \%$ of cases of violations of children's rights are sexual crimes and the rest is physical violence and child abuse. This research uses descriptive qualitative research case. Informants in this study were determined by purposive sampling, several research informants namely the Head of the Protection of Women's Rights and Child Protection in the Office of the Women's Empowerment Office for Child Protection, Population and Family Planning Control and the Office of Education for violence against children in the context of sexual violence every year is always increasing. The results of this study indicate that the strategies and efforts of the Women's Empowerment Office for Child Protection, Population Control and Family Planning (DP3AP2KB) in providing protection and prevention of sodomy victims to elementary school students in the city of Padang can be said to be quite good and but not yet comprehensive in minimizing cases. The strategies used by the P3AP2KB Office have generally been planned and ordered according to stages. However, the strategy used was not optimal due to the inaccurate targeting of the strategy used by the Padang City P3AP2KB Office.
\end{abstract}

Keywords: Sodomy, sexual violence, DP3AP2KB

How to Cite: Anggun dan Aldri Frinaldi. 2019. Strategi DP3AP2KB dalam Memberikan Perlindungan dan Pencegahan Korban Sodomi Siswa Sekolah Dasar di Kota Padang. 3(2): pp. 1-13. DOI: https://doi.org/10.24036/jess/vol3-iss2

\section{Pendahuluan}

Kekerasan seksual mejadi salah satu fenomena yang terjadi di kalangan masyarakat baik itu kekerasan seksual terhadap orang dewasa, remaja maupun anak-anak. Pada saat ini berita mengenai kekerasan seksual banyak dilakukan terhadap anak laki-laki yang mana sudah tercatat di dalam laporan kinerja Komisi Perlindungan Anak Indonesia dalam kurun waktu 8 (delapan) tahun terakhir jumlah korban dan pelaku pelanggaran anak mencapai 33.914 orang dengan jumlah korban dan pelaku didominasi oleh laki-laki. Kekerasan seksual pada lakilaki dikenal dengan istilah sodomi, sodomi menurut Kamus Besar Bahasa 
Indonesia merupakan hubungan seksual penetrative, dimana puncak kepuasaan seksual dilakukan dengan cara memasukkan alat kelamin kedalam dubur, biasanya dilakukan oleh sesama laki-laki, meski bisa dilakukan oleh laki-laki terhadap perempuan. Dinas P3AP2KB merupakan organisasi perangkat daerah (OPD) yang bergerak dalam memberikan perlindungan kepada perempuan maupun anak-anak yang menjadi korban kekerasan seksual. Dinas P3AP2KB memiliki strategi dalam melaksanakan meminimalisir terjadinya kekerasan seksual terhadap anak. Merujuk kepada pengertian strategi menurut Stephanie K. Marrus Umar (2005) strategi merupakan penyusuna suatu upaya dan cara untuk organisasi mencapai suatu tujuan jangka panjang yang ingin dicapai. Menurut Frinaldi \& Akmal, (2011) anak ialah anggota yang tidak dapat dipisahkan dalam kehidupan manusia yang nantinya menjadi sebuah kekayaan dalam lingkungan masyarakat berguna bagi bangsa dan negara. Dalam konstitusi atau hukum Indonesia, anak menjadi prioritas utama dan mempunyai peran penting yang tertuang dalam Undang-Undang No. 35 Tahun 2014 bahwa negara melindungi dan menjamin hak untuk berlangsung, tumbuh, berkembang, dan melindungi anak Indonesia dari kekerasan dan diskriminasi. Maka hal utama yang patut dipahami dan dihayati yaitu kepentingan menjaga dan memberi perlindungan bagi keberlangsungan hidup anak di dunia. Komisi Perlindungan Anak Indonesia (KPAI) mendata terkait dengan kasus kejahatan anak khususnya anak laki-laki terus mengalami peningkatan. Banyaknya laporan yang masuk didominasi kejahatan yang korbannya anak laki-laki. Pada tahun 2018 di Aceh terdapat 26 anak menjadi korban, Tangerang 45 anak, Jambi 80 anak, Banyumas 7 anak, Karanganyar 17 anak, Tapanuli Selatan 42 anak, dan di Tasik 6 anak.

Menurut data KPAI (2018) bahwa kejahatan seksual pada anak menyentuh angka 56,46\% dan selebihnya kasus lain seperti kekerasan dan pembuangan anak. Data terkait dengan kekerasan pada anak terus menerus mengalami kenaikan setiap tahunnya. Tahun 2010 tercatat 2.046 kasus kekerasan terhadap anak dengan $42 \%$ diantaranya dikategorikan kejahatan seksual.

Menurut KPAI dari tahun 2011 sudah terjadi terjadi 2.275 kasus kekerasan terhadap anak, 887 kasus diantaranya merupakan kekerasan seksual anak. Angka ini terus meningkat hingga pada tahun 2014 dari bulan Januari sampai April ada 600 kasus kekerasan anak. Data ini bakal meningkat setiap tahunnya jikalau tidak adanya strategi pencegahan dari permasalahan ini.

Mengkaji soal anak yang telah disinggung di atas dan data yang didapat dari beberapa tahun belakangan kasus kekerasan pada anak dalam kontek kekerasan seksual setiap tahunnya selalu meningkat. Hal ini menyebabkan banyak fenomena-fenomena baru dan gangguan mental yang akan dirasakan anak-anak masa kini. Kasus kekerasan pada anak ternyata di Kota Padang juga sangatlah banyak, Berikut data jumlah korban sodomi pada tingkat sekolah dasar di Kota Padang sebagai berikut: 
Tabel 1. Data Rekapitulasi Korban Sodomi Tingkat Sekolah Dasar di Kota Padang Tahun 2018

\begin{tabular}{clc}
\hline No. & \multicolumn{1}{c}{ Nama Sekolah Dasar } & Jumlah Siswa \\
\hline 1 & SDN 08 Lubuk Kilangan & 10 Orang \\
\hline 2 & SDN 12 Padang Besi & 9 Orang \\
\hline 3 & SDN 11 Purus & 8 Orang \\
\hline 4 & SDN 12 Pasar Teluk Kabung & 9 Orang \\
\hline 5 & SDN 27 Koto Tangah & 9 Orang \\
\hline 6 & SDN 10 Bandar Buat & 14 Orang \\
\hline 7 & SDN 08 Padang Besi & 11 Orang \\
\hline 8 & SDN 11 Padang Besi & 9 Orang \\
\hline 9 & SDN 29 Purus & 9 Orang \\
\hline 10 & SDN 16 Anduring & Jumlah Orang \\
\hline & & 96 Orang
\end{tabular}

Sumber: Kantor DP3AP2KB Kota Padang 2018

Dinas Pemberdayaan Perempuan Perlindungan Anak, Pengendalian Penduduk dan Keluarga Berencana (DP3AP2KB) adalah lembaga/intansi yang bergerak dalam melaksanakan perlindungan baik itu terhadap anak-anak perempuan maupun pengendalian penduduk di daerah.

Merujuk ke pengertian tentang anak berdasarkan Undang-Undang No. 35 Tahun 2014 (Undang-undang Dasar Republik Indonesia No. 35 Tahun 2014 Tentang Perlindungan Anak, n.d.) tentang anak, bahwa seseorang dikatakan anak apabila belum berusia 18 (delapan belas) tahun, dan itu juga termasuk anak yang di dalam kandungan. Menurut Undang-Undang No. 35 Tahun 2014 juga disebutkan bahwa, perlindungan anak adalah segala kegiatan untuk menjamin dan melindungi anak dan hak-haknya agar dapat hidup tumbuh, berkembang, dan berpartisipasi secara optimal sesuai dengan harkat dan martabat kemanusian, serta mendapat perlindungan dari kekerasan dan diskriminasi. Ditelaah lebih lanjut berdasarkan pengertian tersebut bahwasanya, peran dari suatu lembaga/ instansi sangat dibutuhkan untuk sekarang ini di Kota Padang, sebab merujuk kembali dari data yang didapatkan penulis bahwa korban sodomi pada siswa dasar di kota Padang selalu mengalami peningkatan tiap tahunnya, melihat hal ini perlu adanya strategi jitu dari Dinas P3AP2KB dalam memberikan perlindungan korban sodomi di kota Padang pada anak-anak sekolah dasar Kota Padang. Pada dasarnya korban sodomi banyak terjadi pada siswa sekolah dasar yang masih sangat minim akan pengetahuan tentang apa itu kekerasan seksual, sodomi dan efeknya.

Dengan adanya fenomena dan permasalahan di atas dalam hal perlindungan korban sodomi pada siswa sekolah dasar di Kota Padang, oleh sebab itu dalam penelitian ini akan membahas mengenai Strategi DP3AP2KB dalam Memberikan Perlindungan dan Pencegahan Korban Sodomi Terhadap Sekolah Dasar di Kota Padang. 


\section{Tinjauan Kepustakaan}

\section{Strategi Perlindungan Korban}

Menurut Ismail Solihin Solihin (2012) strategis merupakan tindakan untuk mencapai tujuan (ways to achive ends). Strategi adalah sebuah rencana yang digabungkan dan terintegrasi dalam menghubungkan lingkungan dan yang dirancang untuk memastikan bahwa tujuan utama organisasi itu dapat dicapai melalui pelaksanaan yang tepat oleh organisasi.

Menurut Mintzberg Solihin (2012), ada lima arti yang saling terkait di dalam sebuah strategi, yaitu sebagai berikut.

a. Strategy as a Plan

Perencanaan untuk lebih memperjelas arah yang ditempuh suatu organisasi secara rasional dalam mewujudkan tujuan-tujuannya. Di dalam konsep strategi sebagai perencanaan Porter xdalam Rangkuti (2009) menyatakan bahwa perencanaan menjadi bagian penting di dalam suatu pelaksanaan strategi untuk sebuah organisasi

b. Strategy as a Pattern

Acuan atau pola yang berkenan dengan penilaian konsistensi ataupun inkonsistensi perilaku serta tindakan yang dilakukan oleh organisasi. Di dalam Startegi as a Pattern Mintzberg dalam Solihin (2012) mengatakan strategi menjadi sebuah pola yang menunjukkan adanya serangkaian tindakan yang dilakukan oleh organisasi dalam mencapai tujuannya.

c. Strategy as a Position

Sudut yang diposisikan oleh organisasi saat memunculkan aktivitasnya. Dalam hal ini strategi menunjukkan berbagai keputusan dan kebijakan yang dipilih oleh suatu organisasi untuk dapat memosisikan organisasinya di dalam lingkungan sekitar

d. Strategy as a Perspective

Suatu perspektif terakait dengan visi yang menghubungkan antara organisasi dengan lingkungannya yang menjadi batas bagi aktivitasnya. Dalam Wulansari dkk (2019) juga menyatakan perspektif ialah sudut pandang bagaimana sebuah organisasi dapat hidup dan bergerak sesuai dengan visi organisasi dalam mencapai tujuannya.

e. Strategy as a Ploy

Rincian langkah taktis organisasi yang berisi informasi untuk mengelabui atau untuk memberi isyarat mengelabui. Strategi as a Ploy menurut Mintzberg dalam Solihin (2012) mengatakan strategi dapat berupa sebuah rencana praktis atau taktik dalam menghadapi permasalahan dalam suatu organisasi, agar organisasi dapat tetap bersaing dan berkompetitor untuk mencapai suatu tujuan yang ingin dicapai bersama.

Dari pembahasan di atas, dapat disimpulkan bahwasanya strategi itu memiliki arti yang mana dikemukakan oleh Mintzberg dalam Solihin (2012) ada lima kategori yang dapat di singkat dengan 5 P (Plan, Pattern, Position, Perspective dan Ploy). Kelima konsep tersebut memiliki keterkaitan di dalam pelaksanaan strategi atau implementasi staretgi di suatu organisasi. 


\section{Ruang Lingkup Korban}

Menurut Arif Gosita Waluyo (2018) korban ialah seseorang yang menderita jasmani dan rohani sebagai tindakan seseorang untuk mencari pelampiasan kebutuhan sendiri atau orang lain yang bertolak belakang dengan kepentingan dan hak asasi yang menderita. Secara yuridis maksud dari korban tercantum dalam Undang-Undang No. 13 Tahun 2006 menyatakan korban ialah seseorang yang mengalami kekerasan dan penderitaan mental, fisik dan kerugian ekonomi yang diakibatkan suatu tindak pidana. Ario Ponco (2013) juga menjelaskan bahwasanya korban itu ialah mereka yang menderita jasmani dan rohani akibat tindakan orang lain atau perbuatan orang lain yang mencari kepentingan hak asasi atas pihak yang dirugikan. Stephen Schafer Oktoriny (2017) mengemu-kakan bahwasanya yang dikatakan sebagai korban memiliki tipe atau ciri-ciri sebagai berikut :

a. Orang yang tidak memiliki kesalahan apa-apa, tetapi tetap menjadi korban

b. Korban secara sadar atau tidak sadar telah melakukan sesuatu yang merangsang orang lain untuk melakukan kejahatan.

c. Mereka yang secara biologis dan sosial potensial menjadi korban. Anakanak, orang tua,orang yang cacat fisik atau mental, orang miskin, golongan minoritas dan sebagainya merupakan orang-orang yang mudah menjadi korban.

d. Korban sebab ia sendiri merupakan pelaku, inilah yang dikatakan sebagai kejahatan tanpa korban. Pelacuran, perjudian, zina merupakan beberapa kejahatan yang tergolong kejahatan tanpa korban. Pihak yang bersalah ialah korban karena ia juga sebagai pelaku.

Berbicara mengenai korban kejahatan pada awalnya tentu korban orang perorangan atau individu. Pandangan begini tidak salah, karena untuk kejahatan yang lazim terjadi dimasyarakat memang demikian terjadi. Misalnya pembunuhan, penganiyayaan, perkosaan, pencurian dan sebagainya. Pada tahap perkembangannya, korban kejahatan bukan saja orang perorangan, tetapi meluas dan kompleks. Persepsinya tidak hanya banyaknya jumlah korban (orang), namun juga korporasi, intitusi, pemerintah, bangsa dan negara. Hal ini juga dapat dinyatakan bahwa korban dapat berarti individu atau kelompok baik swasta maupun pemerintah menurut Arif Gosita dalam Bambang Waluyo (2018).

Lebih luas dijabarkan kembali oleh Abdussalam Waluyo (2018) mengenai korban perseorangan, institusi, lingkungan hidup, masyarakat, bangsa dan negara ialah sebagai berikut :

1. Korban perseorangan ialah setiap orang sebagai individu mendapat penderitaan baik jiwa, fisik, materiil, maupun non materil.

2. Korban institusi ialah setiap institusi mengalami penderitaan kerugian dalam melaksanakan fungsinya yang menyebabkan kerugian berkepanjangan akibat dari kebijakan pemerintah, kebijakan swasta, maupun bencana alam.

3. Korban lingkungan hidup ialah setiap lingkungan alam yang didalamnya berisikan kehidupan tumbuh-tumbuhan, binatang, manusia dan masyaraakat serta semua jasad hidup yang tumbuh berkembang dan kelestariannya sangat tergantung pada lingkungan alam tersebut yang 
telah mengalami gundul longsor, banjir, dan kebakaran yang ditimbulkan oleh kebijakan pemerintah yang salah dan perbuatan manusia baik individu maupun masyarakat yang tidak bertanggung jawab.

4. Korban masyarakat, bangsa, dan negara ialah masyarakat yang diberlakukan secara diskirminatif tidak adil, tumpang tindih pembagiam hasil pembangunan serta hak sipil, hak politik, hak ekonomi, hak sosial, dan hak budaya.

Dengan adanya lingkup korban yang penulis simpulkan bahwasanya lingkup korban terdiri atas bebrapa macam dan memiliki ciri khas masing dalam konteks korban.

\section{Sodomi}

Menurut Abidin Anwar (2016) mengatakan bahwa sodomi atau seksual analisme ialah pemakaian anus untuk bersenggama. Dalam ensiklopedi agam dan filsafat sodomi artinya melakukan hubungan persetubuhan melalui lubang dubur yang dilakukan oleh sesame pria.. kemudian Sodomi ialah istilah hukum yang dipergunakan untuk merunjuk kepada tindakan seks tidak alami, yang bergantung pada yurisdiksinya dapat terdiri atas seks oral atau seks anal atau semua bentuk pertemuan organ non-kelamin dengan alat kelamin, baik dilakukan secara homoseksual maupun heteroseksual. Sodomi juga merupakan sebab langsung menularnya penyakit-penyakit yang sangat membahayakan dan susah untuk disembuhkan. Apalagi jika perbuatan sodomi sudah menjadi perlakuan yang dianggap biasa oleh anak-anak, sehingga pada saat seorang anak menjadi korban sodomi yang merasa itu bukanlah kekerasan sesksual justru mereka akan menikmatinya dan mencari terus mencari korban-koran selanjutnya dalam Akbar, A \& Puar,YA (1996).

Menurut Kamus Besar Bahasa Indonesia mengemukakan bahwasanya sodomi/anal sex berasala dari kata sodom/Shadum, salah satu kota yang warga masyarakatnya menjadi umat dakwah Nabi Luth as, saat ini letaknya di sekitar laut mati, sebuah tempat yang menjadi saksi kemurkaan tuhan yang ditandai dengan letaknya terendah di muka bumi ini dan tidak dapat ditinggali oleh mahluk hidup. Sodomi artinya perbuatan penduduk kota Sodom, yaitu salah satu jenis hubungan seksual penetratif, dimana puncak kepuasaan seksual dilakukan dengan cara memasukkan alat kelamin kedalam dubur, biasanya oleh sesama laki-laki, meski bisa saja laki-laki meyodomi wanita.

\section{Kekerasan Seksual Terhadap Anak}

Menurut Lyness Noviana (2015) Kekerasan seksual adalah segala macam bentuk perilaku yang berkonotasi seksual yang dilakukan secara sepihak dan tidak diharapkan oleh orang yang menjadi sasaran hingga menimbulkan reaksi negatif: rasa malu, marah, tersinggung dan sebagainya pada diri seseorang. Pelecehan seksual terjadi ketika pelaku mempunyai kekuasaan yang lebih dari pada korban. Kekuasaan dapat berupa posisi pekerjaan yang lebih tinggi, kekuasaan ekonomi, "kekuasaan" jenis kelamin yang satu terhadap jenis kelamin yang lain, jumlah personal yang lebih banyak, dsb. Rentang pelecehan seksual ini sangat luas, meliputi: main mata, siulan nakal, komentar yang berkonotasi seks, humor porno, 
cubitan, colekan, tepukan atau sentuhan di bagian tubuh tertentu, gerakan tertentu atau isyarat yang bersifat seksual, ajakan berkencan dengan iming-iming atau ancaman, ajakan melakukan hubungan seksual sampai perkosaan.

Suhandjati Fuadi (2011) mengatakan bahwa seseorang dikatakan sebagai korban kekerasan apabila menderita kerugian fisik, mengalami luka atau kekerasan psikologis, trauma emosional, tidak hanya dipandang dari aspek legal, tetapi juga sosial dan kultural. Bersamaan dengan berbagai penderitaan itu, dapat juga terjadi kerugian harta benda.

The nation center on child abuse and neglect, Chalk (2002) menyebutkan beberapa jenis kekerasan seksual berdasarkan pelakunya, yaitu:

1. Kekerasan yang dilakukan oleh anggota keluarga.

2. Kekerasan yang dilakukan oleh orang lain di luar anggota keluarga.

3. Kekerasan Perspektif Gender.

\section{Hak-hak Korban Sodomi}

Tingginya kasus kekerasan seksual terhadap anak mendorong Ketua Komnas Perlindungan Anak menyatakan bahwa Indonesia telah memasuki masa darurat. Kekerasan seksual terhadap anak merupakan pelanggaran HAM berat dan harus diletakkan sebagai kejahatan luar biasa (extraordinary crime) karena dampak yang ditimbulkannya telah mengancam masa depan generasi bangsa. Dampak kejahatan seksual ini dapat bertahan dalam jangka panjang dan dapat mengakibatkan penyakit atau gangguan psikologis di kemudian hari. Merujuk pada data dan fakta yang terjadi, mengingatkan kita (orangtua dan pemerintah) betapa penting untuk menjaga dan melindungi anak sebagai langkah awal mencegah terjadinya kejahatan seksual baik itu anak laki-laki maupun anak perempuan. Memberantas kekerasan seksual terhadap anak dan tindakan pedofilia harus dilakukan secara tuntas. Dengan melihat varian faktor penyebab, modus, dan sasaran maka upaya ini harus dilakukan secara menyeluruh. Pelibatan semua aktor dan melalui berbagai pendekatan baik itu sosial, psikologi, ekonomi, maupun agama dapat menjadi senjata yang ampuh dalam upaya penyelamatan ini dalam Fuadi (2011).

Penetapan tahun 2014 sebagai Tahun Darurat Nasional Perlindungan Anak dari Kejahatan Seksual merupakan langkah awal yang tepat untuk menunjukkan keseriusan pemerintah dalam melindungi anak. Fatayat NU dalam Probosiwi \& Bahransyaf (2015) mengemukakan langkah dalam melindungi anak dari kasus kejahatan seksual, yaitu.

1. Mewajibkan lembaga perlindungan dan penegakan hukum untuk memprioritaskan kasus kekerasan terhadap anak, menjamin perlindungan dalam penanganannya, dan memastikan penanganan dampak yang dialami korban dan keluarga korban dilakukan secara tepat dan maksimal hingga hasil yang terbaik;

2. Menetapkan kekerasan seksual pada anak sebagai pelanggaran HAM berat dan merevisi batas maksimal hukuman pidana bagi pelaku kekerasan seksual pada anak menjadi hukuman seumur hidup;

3. Memastikan penegakan hukum (law enforcement) yang memenuhi rasa keadilan korban, keluarga korban, dan masyarakat, serta menjatuhkan 
hukuman yang maksimal terhadap pelaku kekerasaan seksual terhadap anak;

4. Menetapkan sanksi tegas hingga pencabutan izin dan penutupan permanen kepada lembaga dan atau institusi yang telah melakukan pembiaraan atau pelalaian terhadap terjaminnya keamanan dan keselamatan anak dari kekerasan jenis apapun;

5. Melakukan monitoring dan evaluasi terhadap seluruh penanganan kasus kekerasaan seksual terhadap anak di seluruh wilayah Indonesia, termasuk penanganan pemulihan pada korban dan keluarga korban;

6. Mewajibkan syarat yang memastikan lingkungan aman dan layak anak serta memberikan pendampingan (technical assistance) bagi upaya perlindungan terhadap keselamatan anak di seluruh lembaga dan institusi yang terdapat kepesertaan anak di dalamnya seperti sekolah, taman anak, PAUD, dan play group.

7. Mewajibkan materi pendidikan kesehatan reproduksi bertahap dan berjenjang kepada anak-anak melalui lembaga dan institusi pendidikan yang diintegrasikan di seluruh level pendidikan yang terdapat kepersertaan anak di dalamnya baik di tingkat pendidikan formal, informal, dan non formal.

8. Melakukan pendampingan (technical assistance), monitoring, dan evaluasi terhadap gerakan perlindungan dan pengamanan terhadap anak di lembaga-lembaga dan atau institusi-institusi yang terdapat kepesertaan anak di dalamnya seperti sekolah, taman anak, PAUD, play group dan lain-lain;

9. Membangun "Rumah Aman Anak" di setiap tingkat kabupaten di seluruh Indonesia dan menjamin penganggarannya sebagai bentuk komitmen pemerintah dalam menangani, memperhatikan, dan memberikan bantuan khusus bagi anak dan keluarga anak yang mengalami kekerasaan, khususnya kekerasan seksual anak;

10. Mengembangkan sosialisasi secara menyeluruh kepada masyarakat tentang pentingnya pendidikan kesehatan reproduksi anak yang tepat dan bertahap serta upaya perlindungan kekerasan terhadap anak agar masyarakat memiliki pengetahuan (knowledge), kepedulian (awareness), dan penanganan (take action) dalam kasus kekerasan seksual terhadap anak;

11. Memaksimalkan kerjasama pemerintah dengan semua pihak yang berkepentingan (multi stakeholder) dalam kasus kekerasan seksual terhadap anak, baik dengan lembaga swadaya masyarakat, ormas, perkumpulan, perserikatan, dan atau individu-individu masyarakat yang peduli terhadap kekerasan seksual terhadap anak.

Langkah perlindungan anak dari kejahatan seksual juga harus dilakukan dari dalam. Keluarga harus menjadi tempat perlindungan pertama anak. Orangtua harus waspada dan memberikan bekal yang cukup bagi anak terkait keselamatan seksual mereka. Pendidikan seksual dapat diberikan sedini mungkin melalui kata dan kalimat yang sederhana namun tepat dan tidak vulgar. Penggunaan istilah sebenarnya akan membantu anak dalam mengkomunikasikan kejahatan seksual 
yang mungkin ia alami. Komunikasi yang baik antara anak dengan orangtua juga dipercaya mampu melindungi anak dari kejahatan seksual, paling tidak anak tidak akan menutupi kejadian yang dialaminya. Menghargai privasi dan naluri ana misal tidak mau bersalaman dengan seseorang akan membuat anak belajar mempertahankan dan menjaga apa yang dimilikinya.

\section{Metode Penelitian}

Jenis penelitian ini adalah jenis penelitian kualitatitf deskripif. Lokasi penelitian dilaksanakan penulis di Dinas Pemberdayaan Perlindungan Anak, Pengendalian Penduduk dan Keluarga Berencana (DP3AP2KB). Informan dalam penelitian ini menggunakan teknik penentuan informan (pusposive sampling). Penelitian ini menggunakan jenis dan sumber data dari data primer dan data sekunder. Teknik pengumpulan data dikumpulkan melalui wawancara, observasi dan dokumentasi, kemudian dalam teknik analisis data menggunakan langkah-langkah analisis data yaitu reduksi data, penyajian data dan verikasi data dalam mendapatkan kesimpulan dari penelitian. Tingkat kepercayaan atau tingkat validitas penelitian ini menggunakan teknik trianggulasi sumber dimana kepercayaan atau informasi diperoleh melalui orang-orang (sumber) yang berbeda dengan cara membandingkan data hasil, membandingkan apa yang dikatakan di depan umum, membandingkan apa yang dikatakan instansi dan juga membandingkan hasil wawancara dengan isi dokumen yang berkaitan dengan penelitian.

\section{Hasil Penelitian dan Pembahasan}

\section{Strategi dari Dinas Pemberdayaan Perempuan Perlindungan Anak, Pengendalian Penduduk dan Keluarga Berencana (DP3AP2KB) dalam Memberikan Perlindungan dan Pencegahan Korban Sodomi Terhadap Siswa Sekolah Dasar di Kota Padang}

Penelitian ini menggunakan konsep strategi menurut Mintzberg Solihin, (2012) yang mana konsep strategi memiliki lima arti yang saling terkait, yaitu perencanaan, acuan atau pola, posisi, perspektif dan langkah taktis. Strategi yang digunakan oleh Dinas P3AP2KB umumnya sudah terencana dan berurut sesuai tahapan. Dinas P3AP2KB tidak berdiri sendiri dalam memberikan perlindungan dan pencegahan korban sodomi, mereka bekerjasama dengan pihak lainnya seperti Dinas Pendidikan, kepolisian,dan Dinas Kesehatan. Menurut Mintzberg Solihin, (2012) mengatakan bahwa strategi yang yang baik dapat terlaksana dilihat dari arti dari strategi itu sendiri, adanya perencanaan yang dibuat akan memudahkan organisasi dalam melaksanakan kinerjanya masing-masing.

Kenyataannya, strategi yang digunakan oleh Dinas P3AP2KB dalam memberikan perlindungan dan pencegahan korban sodomi dengan melakukan sosialisasi kepada Kepala Sekolah, Guru dan Wali Murid Siswa Dasar yang ada di Kota Padang belum maksimal, karena sosialisasi hanya sebatas pada perangkat sekolah. Sedangkan untuk wali murid hanya beberapa saja yang tahu akan sosialisasi tersebut. Sosialisasi yang dilakukan oleh Dinas P3AP2KB ini terkesan 
dilakukan hanya untuk sekolah dasar yang memiliki permasalahan yang berat. Padahal menurut Hamel dan Prahalad Rangkuti (2009) mengatakan strategi itu ialah tindakan yang bersifat incremental (senantiasa meningkat) dan terus dilakukan berdasarkan sudut pandang tentang apa yang diharapkan oleh para masyarakat di masa depan. Dengan demikian strategi yang seharusnya digunakan oleh Dinas P3AP2KB dimulai dari "apa yang dapat terjadi" bukan dari "apa yang terjadi”. Sehingga perencanaan strategi yang sudah dilakukan Dinas P3AP2KB tidak memberikan hasil yang maksimal sesuai dengan tujuan jangka panjang yang ingin dicapai.

Dinas P3AP2KB di dalam perencanaannya memiliki program melakukan kegiatan sosialisasi kepada Kepala Sekolah seKota Padang, Guru BK dan Wali Murid. Selain itu, membentuk tim Perlindungan Anak Terpadu Berbasis Masyarakat (PATBM) yang tersebar di 104 kelurahan yang ada di Kota Padang dan sekaligus bekerjasama dengan Dinas Pendidikan. Dinas pendidikan juga membentuk tim yang dinamakan TRC (Tim Reaksi Cepat) dalam memberikan perlindungan kepada anak. Faktor utama dari adanya kekerasan seksual seperti sodomi yaitu orang tua sekarang terlalu cepat memberikan gadget dan kurangnya perhatian orang tua kepada anak yang membuat anak menjadi bebas mengakses berbagai situs pornografi di internet. Acuan atau pola yang digunakan oleh Dinas P3AP2KB adalah dengan cara menelusuri terdahulu persoalan yang terjadi kemudian melakukan pengamatan dan nanti akan langsung diberikan sosialisasi terhadap kepala Sekolah guru dan wali murid selain itu juga berkerjasama dengan Dinas Pendidikan. Sedangkan Dinas Pendidikan acuan di dalam strategi untuk melindungi dan mencegah sodomi pada siswa Sekolah Dasar dengan membentuk Tim Reaksi Cepat dan bekerjasama dengan pihak kepolisian. Dinas P3AP2KB dan Dinas Pendidikan dalam perlindungan dan pencegahan korban sodomi terhadap siswa Sekolah Dasar di Kota Padang mendapat pandangan atau perspektif masyarakat umumnya diberikan respon positif baik dari pihak sekolah maupun dari pihak masyarakat. Kemudian langkah taktis Dinas P3AP2KB dalam perlindungan dan pencegahan korban sodomi terhadap siswa Sekolah Dasar di Kota Padang dilakukan dengan cara membawa anak-anak ke psikiater dan memberikan motivasi dan semangat. Sedangkan Dinas Pendidikan mendata persoalan terlebih dahulu dan baru akan ditangani. Dari program yang dilakukan kedua dinas mendapatkan perubahan, manfaat dan respon yang cukup baik.

\section{Upaya dari Dinas Pemberdayaan Perempuan Perlindungan Anak, Pengen-dalian Penduduk dan Keluarga Berencana (DP3AP2KB) dalam Memberikan Perlindungan dan Pencegahan Korban Sodomi Terhadap Siswa Sekolah Dasar di Kota Padang}

Berdasarkan hasil wawancara yang dilakukan maka upaya dari Dinas Pemberdayaan Perempuan Perlindungan Anak, Pengendalian Penduduk dan Keluarga Berencana (DP3AP2KB) dalam memberikan perlindungan dan pencegahan korban sodomi terhadap siswa Sekolah Dasar di Kota Padang sudah baik tetapi belum menyeluruh dan maksimal. Dikarenakan sosialiasasi hanya ke kepala sekolah dan guru sedangkan untuk wali murid belum semuanya 
mendapatkan sosialiasi dari dinas tersebut. Menurut kamus Etismologi upaya mempunya arti yang pendekataan untuk mencapai suatu tujuan. Kemudian dalam

Kamus Besar Bahasa Indonesia disebutkan juga bahwasanya upaya ialah suatu aktifitas yang mengarahkan pikiran dan tenaga sebagai usaha untuk mencapai suatu tujuan yang diinginkan dalam mencari jalan keluar dalam suatu permasalaha

Nawawi (2010) mengungkapkan bahwasanya didalam upaya terbagi atas 3 kategori yaitu pre-emtif, preventif, represif. Pre-emtif Merupakan segala upayaupaya awal yang dilakukan suatu organisasi untuk mencegah terjadinya suatu pelanggaran. Upaya-upaya yang dilakukan secara pre-emtif melalui nilai-nilai dengan menanamkan norma-norma yang baik supaya norma dan nilai tersebut dapat meresap pada mereka.Upaya dari Dinas P3AP2KB yaitu dengan melakukan sosialisasi kepada kepala sekolah, guru dan wali murid. Kemudian Dinas

P3AP2KB juga menjadikan visi sebagai landasan meningkatkan penguatan kelembagaan perempuan dan gender serta meningkatkan kualitas hidup keluarga, perlindungan perempuan dan anak. Selanjutnya Dinas P3AP2KB juga membuat sebuah tim yang mana tim ini sudah diresmikan pada November 2018 lalu yang disebut dengan tim Perlindungan Anak Terpadu Berbasis Masyarakat yang mana tim ini sudah disebarkan kepada 104 kelurahan yang ada di Kota Padang.

Harapannya tim Perlindungan Anak Terpadu Berbasis Masyarakat ini yang nantinya dapat memantau dan menangani permasalahan kekerasan seksual yang terjadi pada anak di Kota Padang seperti sodomi. Selanjutnya upaya Preventif ialah kategori kedua dalam sebuah upaya. Upaya preventif ini adalan tindak lanjut padatahapan pencegahan sebelum terjadinya sebuah permasalahan atau pelanggaran. Di dalam upaya preventif ini Dinas P3AP2KB sudah melakukan

beberapa pencegahan yang mana dilakukan dengan cara berkerjasama dengan instansi atau lembaga lain yang ada di Kota Padang, seperti berkerjasama dengan Dinas Pendidikan kemudian juga mendapat bantuan dari Pihak Dinas Kesehatan dalam memberikan terapis gratis kepada anak yang mengalami kekerasan seksual dan pelecehan seksual. Dinas P3AP2KB juga mendapat bantuan dari pihak kepolisian dalam menangkap pelaku dan memberikan hukuman kepada pelaku tersebut.

Upaya Represif merupakan upaya yang dilakukan dengan cara melakukan suatu tindakan setelah terjadinya permasalahan atau peritiwa yang buruk dalam Nawawi (2010). Dinas P3AP2KB melakukan tindakan kepada sekolah yang masih bungkam atau terkesan menutup-nutupi permasalah yang terjadi disekolah dengan cara pendekatan emosional dan langsung terjun kelapangan melihat permasalahan yang terjadi disekolah tersebut. Setelah itu Dinas P3AP2KB akan melakukan evaluasi dan berdiskusi dengan beberapa pihak seperti Dinas Pendidikan bahkan juga berdiskusi dengan Bapak Mahyeldi Selaku Walikota Padang. Strategi yang digunakan oleh Dinas P3AP2KB dalam memberikan perlindungan dan pencegahan korban sodomi dengan melakukan sosialisasi kepada Kepala Sekolah, Guru dan Wali Murid Siswa Dasar yang ada di Kota Padang belum maksimal, karena sosialisasi hanya sebatas pada perangkat sekolah. Sedangkan untuk wali murid hanya beberapa saja yang tahu akan sosialisasi tersebut. Kepala Sekolah, Guru dan Wali Murid berharap sosialisasi ini juga diberikan kepada siswa Sekolah Dasar yang terkena kekerasan seksual ataupun 
yang belum mengalami itu. Sebab yang lebih merasakan dampaknya ialah anak. Sosialisasi dapat diberikan dalam bertahap namun lebih ditekan kepada Wali Murid dan anak-anak. Sosialisasi yang dilakukan oleh Dinas P3AP2KB ini terkesan dilakukan hanya untuk sekolah dasar yang memiliki permasalahan yang berat. Padahal menurut Hamel dan Prahalad Ranguti (2009) mengatakan strategi merupakan suatu tindakan yang bersifat incremental (senantiasa meningkat) dilakukan berdasarkan pandangan tentang yang diharapkan oleh masyarakat di masa yang akan datang.

Upaya yang lain dilakukan oleh Dinas P3AP2KB ialah melakukan crosscheck ke lapangan dan membuat pelaporan terkait permasalahan yang terjadi di Sekolah. Selanjutnya dari Dinas P3AP2KB akan mengambil langkah taktik dan menindak lanjuti persoalan ini dan langsung berdiskusi dengan instansi yang berkejasama dengan Dinas P3AP2KB untuk mendapatkan solusi, sehingga solusi ini menjadi upaya dari Dinas P3AP2KB dalam memberikan perlindungan dan pencegahan korban sodomi terhadap siswa sekolah dasar di Kota Padang.

\section{Kesimpulan}

1. Strategi Dinas Pemberdayaan Perempuan Perlindungan Anak, Pengendalian Penduduk dan Keluarga Berencana (DP3AP2KB) dalam memberikan perlindungan dan pencegahan korban sodomi terhadap siswa Sekolah Dasar di Kota Padang dapat dikatakan sudah cukup baik tapi belum menyeluruh dalam meminimalisir kasus. Strategi yang digunakan oleh Dinas P3AP2KB umumnya sudah terencana dan berurut sesuai tahapan. Tetapi, strategi yang digunakan belum tepat sasaran, karena sosialisasi hanya sebatas pada perangkat sekolah. Sedangkan untuk wali murid hanya beberapa saja yang tahu akan sosialisasi tersebut. Berharapnya sosialisasi ini juga diberikan kepada anak-anak yang mengalami kekerasan seksual maupun yang belum mengalaminya, sebab yang merasakan gangguan mental atau traumatis adalah anak-anak sehingga edukasi dan sosialisasi yang berstandar anak-anak perlu juga diberikan. Sosialisasi yang dilakukan oleh Dinas P3AP2KB ini terkesan dilakukan hanya untuk sekolah dasar yang memiliki permasalahan yang berat.

2. Upaya dari Dinas Pemberdayaan Perempuan Perlindungan Anak, Pengendalian Penduduk dan Keluarga Berencana (DP3AP2KB) dalam memberikan perlindungan dan pencegahan korban sodomi terhadap siswa Sekolah Dasar di Kota Padang akan lebih gencar lagi memberikan sosialisasi kepada Kepala Sekolah, Guru dan Wali Murid. Kemudian upaya yang dilakukan cukup baik dan telah berusaha maksimal tetapi upaya yang dilakukan belum menyeluruh ke semua sektor dan kurang tepat sasaran.

\section{DAFTAR KEPUSTAKAAN}

Abidin,Anwar.2016. Prilaku Penyimpangan Seksual dan Upaya Pencegahannya di Kabupaten Jombang. Maret 2016. 
Ahmad Nawawi. 2013. Partisipasi Masyarakat dalam Pengelolaan Wisata Pantai Depok di Desa Kretek Parangtritis. Jurnal Nasional Pariwisata. Volume 5, Nomor 2, Agustus.

Chalk, R. (2002). The multiple dimensions of child abuse and neglect: New insights into an old problem. Child Trends Research Brief, May(May), 1-8.

Frinaldi, A., \& Akmal. (2011). Analisis Dimensi Hak Asasi manusia Terhadap Putusan Hakim Dalam Perkara Pencabulan Anak Di Bawah Umur (Analisis Konten: Perkara No. 166/PID.B/2006/PN PDG). X, 36-37.

Fu'ady, M. A. (2011). Dinamika Psikologis Kekerasan Seksual: Sebuah Studi Fenomenologi. Psikoislamika : Jurnal Psikologi Dan Psikologi Islam, 8(2), 191-208. https://doi.org/10.18860/psi.v0i0.1553

KPAI. (2018). LAPORAN KINERJA KPAI TAHUN 2018 ( Peningkatan Efektivitas Kinerja Pengawasan Penyelenggaraan Perlindungan Anak di Indonesia ). Jakarta.

Nawawi. (2010). Kebijakan Legislatif dalam Penanggulangan Kejahatan Dengan Pidana Penjara. Yogyakarta: Genta Publishing.

Noviana,Ivo. 2015. Kekerasan Seksual Terhadap Anak: Dampak dan Penangannya Child Sexual Abuse: Impact adn Hendlig. 15 Maret 2015.

Oktoriny, F. (2017). Perlindungan Anak Dalam Proses Peradilan Pidana. 5, 7576.

Ranguti, F. (2009). Analisis SWOT Teknik Membedah Kasus Bisnis (Reorientasi Konsep Perencanaan Strategis Untuk Menghadapi Abad 21) (Ke 6). Jakarta: PT Gramedia Pustaka Utama.

Ratih Probosiwi dan Daud Bahransyaf. (2015). Pedofilia dan Kekerasan Seksual: Masalah dan Perlindungan Terhadap Anak. 01, 36-37.

Solihin, I. (2012). Manajemen Strategik (A. Maulana, ed.). Jakarta: Penerbit Erlangga.

Umar, H. (2005). Strategic Management in Action (Ke-4; Sukoco, ed.). Jakarta.

Undang-undang Dasar Republik Indonesia No. 35 Tahun 2014 Tentang Perlindungan Anak. (n.d.). Perlindungan Anak.

Waluyo, B. (2018). Viktimologi ( Perlindungan Korban dan Saksi ) (Ke-VI; Tarmizi, ed.). Jakarta: Sinar Grafika. 
